\title{
Influence of the literati aesthetic taste of Art
}

\author{
Zhang Haiyan \\ Lanzhou Jiaotong UniversityArt and design institute, Lanzhou, Gansu province 730070, China
}

Key Words. The Song Dynasty, scholars, aesthetic taste, arts and crafts, impact

\begin{abstract}
The Song dynasty is the period in which thelevel of arts and crafts is relatively perfect, since the Song dynasty, Chinese people gradually formed such an aesthetic standard: "The peep of lotus flower” (freshly and beautifully) is much better than "The gorgeously wrought”. It is the Song dynasty when the literati appeared real and comprehensive, literati culture was gradually mature and perfect. During the whole aesthetic trend of that age, the literati's aesthetic orientation gradually became the mainstream of social development, scholars were the major consumer groups of Song dynasty. Their consumption has a direct impact on the arts and crafts' production and manufacturing. From the economic perspective, in Song dynasty these literati's aesthetic interest played a great role in craft art history. The literati have increased the velocity of circulation in the arts and crafts market. This paper will mainly analyze and discuss the influence of the aesthetic taste of literati in the Song dynasty on the direct influence of Chinese arts and crafts style at that time.
\end{abstract}

\section{Introduction}

The Song dynasty is the period in which the level of arts and crafts is relatively perfect, since the Song dynasty, Chinese people gradually formed such an aesthetic standard: "The peep of lotus flower" (freshly and beautifully) is much better than "The gorgeously wrought”. In Song dynasty, the plain, elegant style of arts and crafts became the mainstream. The clothing, textile, ceramics, furniture or lacquer were in the plain style, without overelaborate, colorful redundant adornment, from which people can feel the beauty of elegance and delicate. In terms of aesthetic perspective, the Song dynasty's technology has an elegant style of art.The literati's aesthetic taste have a direct impact on the artstyles in Song dynasty. Zhao Kuangyin Song Taizu feared the warlords who may usurp his throne. So he just lowered the power of military officers as much as he could, and prompted the civil official as high as he could, that policy largely improved those civil official's image, then made those literati became admirable. When the government implemented the policy of "heavy text light arms" it has widely popularized the education in Song dynasty.[1] In the aspect of education objects, Song dynasty has brooked the limited of noble education and encouraged the poor to take the examination, which had improved the image of cavil officials (scholars). Scholars have gradually become admirable in Song dynasty.

When the government implemented the policy of "heavy text light arms" it has widely popularized the education in Song dynasty. In the aspect of education objects, Song dynasty has brooked the limited of noble education and encouraged the poor to take the examination, relaxed the admission level limit in the school system, the students number has increased. On the one hand, children education developed rapidly, on the other hand Song government began to pay attention to women's education. From that, the bureaucrats, the landlords and even the ordinary people have constructed a culture class which hasmore dimensions and upbringings than Tang dynasty. In addition, in terms of ideology and culture, the literati had launched a large-scale and comprehensive 
development in the Song dynasty, which called "culture booming”. In such a cultural atmosphere, a large literati class was naturally growing. Compared with the former generation of literati, these scholars in Song dynasty were more consciously, their creation revealed their literati character, and this character has permeate in the arts and craft culture artworks. All the artworks showed the literati character of pure, plain, nature and elegant.

\section{The influence of Confucianism culture on Song dynasty literatiaesthetic taste}

The complementation in Confucianism culture is an important feature of the literati class. Confucianism and Taoism have both focused on the connotation, introversion, and they won't be disturbed by the surface. All these characteristics manifest in Confucianism as the introspection and pray. In Confucian, a gentleman should "take self-reflections three times a day", "do not fear being unknown, but ignorant”. That is to say, we should build a modest character, and take self-reflections before we take actions. Confucianism thinks highly of the personal moral cultivation, the Taoist stressed the theory of Stillness and non-action, it has point out clearly that the word Tao should be “laws, nature and naïve”. The great form has no shape, the great sound is hard to hear, Tao can't be expressed by a specific way. Lao-tzu the founder of Taoist, says in Lao-tzu chapter 12th "Nimiety words make one deaf, plethora colors make one blind, various flavors make one feel tasty, rare goods make one puzzled, wild hunt make one crazy.[2]

Chen Gu explained it as: the "desire of heart" means the construction of quiet life; the "desire of material" means the pursuit of life; the "leave and left" has showed a right way for the men. The Taoist had espoused to build a stable world in their mind, not detach and empty, like the concept "Tao". "Tao" is the combination of "all" and "nothing", that showed "Tao" is an activity process which origin from intangible image to tangible. Therefore "the soft can defeat the stiffness" just advocated by Lao Tzu, the founder of Taoism, the core thought is the fully manifestsof "the introversion". The literati became the intermediary, the artworks in Song dynasty has a strong characteristics especially in the pottery artworks. The artworks in Song dynasty almost have no decoration at all, they win with the pure glaze and classical modelling, which has big difference in Tang and Yuan dynasty.

\section{The influence of the aesthetic taste of literati in the Song Dynasty on arts and crafts}

The aesthetics of science spawned by Neo-Confucian aesthetics. Neo-Confucianism in Song Dynasty has the greatest influenceon art and aesthetics. The core of Neo-Confucianism is the beauty of personality, emphasis on the inheritance of tradition Confucian aesthetic, integrate the Aesthetics of science, furthering the development of Neo-Confucianism.Based on the inheritance of tradition aesthetic intuitionNeo-Confucianism have payed more attention tothinks and analysis. The implication, artistic thinking and art form of poetry in Song dynasty are largely affected by Neo-Confucianism, which means the aesthetic of Neo-Confucianism contamination was extremely profound. This Aesthetic concept of Neo-Confucianism had become the power source of aesthetics in Song dynasty.In a quiet and peaceful environment people in Song dynasty put forward the "light", "distant" and "rhyme" as the new aesthetic standard. The literati in Song dynasty had a deep understanding of "rhyme", they thought "one with high morals shall has its rhyme", "the surplus mind is the rhyme" and "rhymes are all in the books". Thus, after fully tasted of the "light", "distant" and "rhyme", literati furthered the aesthetic standard in Song dynasty, which had a great impact on the arts and crafts style and landscape painting creation.[3] 
The literati tastes of "Shangri-La" in Song dynasty. In ancient China, people call peach-garden the "utopia", the peach-garden is the poetic practice and incarnation of "small territory and population" and "laissez-faire", in order to attract a large number of later generations of literati and liberal intellectuals who are searching for the peach-garden the "Shangri-La". Those hermits cultivate their morality to reach a higher and wiser state. Literati in Song dynastyaspire to live freely, this intention is the eternal aim of human race.Inferior imitate of nobility is an immutable law in Chinese craft art history, like the low material implements imitation high material objects. However in the Song dynasty, many porcelain was modelling the bamboo basket, at that time, the price of porcelain is more expensive than the bamboo, from which we can see the influence of literati taste in arts and crafts.The model has fully demonstrated the literati in Song dynasty, and theyare very yearning the rural fishing life [4]. In addition, literati in Song dynasty are also fondof the classical literaturestyle, extremely in "Shangyizhouding" when they collect the artworks they also imitate it. The imitator included both the ordinary people and the royal family. The epigraphy was first risen in Song dynasty, including the catalogue of epigraphyand the collection of ancient records.In fact, whether they like the old times or the seclusion, its the internal performance of escape behavior. Theywanted to tell people that they lost faith with the reality society, and showedno interest in secular society. They can defeat the temptation of realitywealth, and ensure that the ascension of spiritual.

\section{The aesthetic taste of the literati in the Song Dynasty is a direct mapping of the arts and crafts style.}

The establishment of the core position of literati aesthetic was just behind the birth of the literati class.Although the members of the class are extensive, they were also active in the political arena, linked closely with the social's value orientation, which was asignificant characteristic of Song dynasty. No matter from the spiritual or material, the literati lived an easy life in Song dynasty like the fish in the water. Influenced by the traditional aesthetic standard, our arts and crafts were mainly divided into two parts: natural and lovely, or gorgeously wrought. These styles have been reflected in all kinds of art and crafts in different types and ages. The literati hadmadea great effort in development of such an aesthetic ideal. Basically, the Song dynasty is the era when the literati class was fully grow, their aesthetic tastes could represent the mainstream of aesthetic concept of the whole society. Such as Sushi his articles were matured with his age, the natural spirits and the aesthetic tastes in the articles became the highest state which the literati kept searching in the Song dynasty. The austere clothing, the plain textile technology and the modest lacquerware, they are the materiel expression of the literati's aesthetic tastes. And these tastes have become the mainstream of arts and crafts aesthetic thought after thousands of years in our country. [5] The literati was the major consumer groups of artworks, their consumption direct effect to the arts and crafts' production and manufacturing. From the economic perspective, in Song dynasty these literati's aesthetic interest played a great role in craft art history.

In addition, the social influence of literati class, their cultural identity and the influence of the aesthetic tastes in arts and crafts such are worthy of a further research. We can find the inevitability and the rationality of the literati's aesthetic tastes from the leading power of arts and crafts' development model and direction. 


\section{Conclusions}

To sum up, there has some factual evidences about the elite culture and theliterati's aesthetic tastes which had a great impact on arts and crafts. After the further study on the development of arts and crafts in our country, we found the influence that the improvement of arts and crafts have decided the style of elegance and refinement. To some extent, the impact of their action was guiding the direction of the arts and crafts. The literati class also played a key role in the tendency of consumption and the style of aesthetic on the arts and crafts.To a great extent, their aesthetic standards and ideological standards had affected the style of Chinese arts and crafts.

\section{References}

[1] Liu Guangyu. The study of Southern Song Dynasty porcelain kilnunearthed from the Wang Xianshi family tombs [J]. The Silk Road, 2014 (10) : 148-149.

[2] Feng Xiulian. Aesthetic thoughts of Neo-Confucianism in the architectural form of Song dynasty [J]. The Beauty andTime (part 1), 2013 (7) : 120-121. 